\title{
Pemberdayaan Masyarakat di Kampung Kroyo, Karangmalang Sragen dalam Penerapan PHBS sebagai Upaya Pencegahan dan Penanggulangan Covid-19
}

\author{
https://doi.org/10.32509/am.v4i1.1299
}

\author{
Aisyah Nur Mutmainah ${ }^{1}$, Makhabbah Jamilatun ${ }^{2}$ \\ 1,2 Jurusan Anafarma Poltekkes Kemenkes Surakarta \\ Jl. Ksatrian, Danguran, Klaten Selatan - Indonesia \\ Email Korepondensi: makhabbah.j@gmail.com
}

\begin{abstract}
PHBS is carried out in order to prevent the onset of diseases, overcome diseases and other health problems. During the Covid-19 pandemic, PHBS can be applied in community to break the chain of spreading the virus. The proper application of PHBS by every community is said to be the most effective way to prevent infection and spread of the virus so that it can reduce the incidence of Covid-19. Based on observations at the beginning of the pandemic, the people around Kroyo Village, Karangmalang, Sragen, have not all implemented PHBS. Therefore, community service activity is carried out through community empowerment in Kroyo Village, Karangmalang, Sragen in implementing PHBS as an effort to prevent and overcome covid-19. The activity method used in these community service activity is community empowerment in the application of PHBS and efforts to overcome covid-19. With this community service activity, residents can understand and implement PHBS so that cases of Covid-19 transmission in the Kroyo Village Area, Karangmalang, Sragen can be prevented and controlled.
\end{abstract}

Keywords:. empowerment, PHBS, covid-19

\begin{abstract}
Abstrak - PHBS dilakukan dalam rangka mencegah timbulnya penyakit, menanggulangi penyakit dan masalah-masalah kesehatan lain. Di masa pandemi Covid-19, PHBS dapat diterapkan di masyarakat untuk memutus mata rantai penyebaran virus. Penerapan PHBS yang tepat oleh setiap masyarakat disebut sebagai cara yang paling efektif dalam mencegah infeksi dan penyebaran virus sehingga dapat menekan angka kejadian Covid-19. Berdasarkan observasi di awal waktu pandemi, masyarakat di sekitar Kampung Kroyo, Karangmalang, Sragen, belum semuanya menerapkan PHBS. Oleh karena itu, dilakukan kegiatan pengabdian kepada masyarakat melalui pemberdayaan masyarakat di Kampung Kroyo, Karangmalang, Sragen dalam penerapan PHBS sebagai upaya pencegahan dan penanggulangan covid-19. Metode kegiatan yang digunakan dalam kegiatan pengabdian masyarakat ini adalah pemberdayaan masyarakat dalam penerapan PHBS dan upaya penanggulangan covid-19. Dengan adanya kegiatan pengabdian kepada masyarakat ini warga dapat memahami dan menerapkan PHBS sehingga kasus penularan covid-19 di Wilayah Kampung Kroyo, Karangmalang, Sragen dapat dicegah dan dikendalikan.
\end{abstract}

Kata kunci: pemberdayaan, PHBS, covid-19

\section{PENDAHULUAN}

PHBS, kepanjangan dari Perilaku Hidup Bersih dan Sehat, merupakan sekumpulan perilaku yang dipraktekkan atas dasar kesadaran sebagai hasil pembelajaran yang menjadikan individu atau keluarga atau kelompok dapat menolong dirinya sendiri dalam bidang kesehatan dan berperan aktif dalam mewujudkan derajat kesehatan masyarakat (Kementerian Kesehatan, 2016). PHBS merupakan langkah yang harus dilakukan untuk mencapai derajat kesehatan yang optimal bagi setiap orang. Upaya ini dimulai dari menanamkan pola pikir sehat kepada masyarakat dan diusahakan oleh diri sendiri, sebagai usaha untuk mewujudkan derajat kesehatan masyarakat. PHBS dilakukan dalam rangka mencegah timbulnya penyakit, menanggulangi penyakit dan masalah-masalah kesehatan lain. Di masa pandemi Covid-19, PHBS dapat diterapkan di masyarakat untuk memutus mata rantai penyebaran virus.

Sebagaimana diketahui wabah Covid-19 telah dianggap sebagai darurat kesehatan global. Secara internasional, jumlah laporan yang dikonfirmasi terus meningkat (Sohrabi, 2020). Indonesia pertama 
kali melaporkan 2 kasus positif covid-19 pada bulan Maret 2020 yang diiringi dengan terus meningkatnya kasus positif (Susilawati, 2020). Berbagai badan kesehatan termasuk WHO dan US Centers for Disease Control and Prevention (CDC) telah mengeluarkan saran untuk mencegah penyebaran Covid-19 lebih lanjut. Langkah-langkah pencegahan yang direkomendasikan di antaranya mencuci tangan, menutup mulut saat batuk, menjaga jarak dari orang lain, serta pemantauan dan isolasi diri untuk orang yang mencurigai bahwa mereka terinfeksi, hanya saja belum semua masyarakat mentaati hal ini (Rothan dan Byrareddy, 2020; Beiu et al., 2020).

Penerapan PHBS yang tepat oleh setiap masyarakat disebut sebagai cara yang paling efektif dalam mencegah infeksi dan penyebaran virus sehingga dapat menekan angka kejadian Covid-19 (Karo, 2020; Tabi'in, 2020; Zukmadini, et al, 2020). Anjurkan untuk rajin mencuci tangan dengan sabun dan air bersih yang mengalir sebagai kunci utama memutus mata rantai penyebaran virus, tampak mudah dilakukan, tetapi pada dasarnya sulit diterapkan secara konsisten di masyarakat karena merupakan sebuah tindakan yang relatif baru dan belum menjadi kebiasaan di masyarakat. Penyuluhan tentang PHBS berhasil memahamkan masyarakat akan pentingnya perilaku hidup bersih dan sehat dalam kehidupan sehari-hari (Jamilatun, 2019; Jamilatun, 2020). Sehingga dalam kondisi pandemi seperti saat ini, penyuluhan tentang PHBS penting dilakukan untuk memberikan pemahaman masyarakat pentingnya PHBS dan mengingatkan masyarakat pentingnya penerapan PHBS terutama sebagai upaya pencegahan covid-19.

Berdasarkan observasi di awal waktu pandemi, masyarakat di sekitar Kampung Kroyo, Karangmalang, Sragen, belum semuanya menerapkan PHBS. Oleh karena itu, dilakukan kegiatan pengabdian kepada masyarakat melalui Pemberdayaan Masyarakat di Kampung Kroyo, Karangmalang, Sragen dalam Penerapan PHBS sebagai Upaya Pencegahan dan Penanggulangan Covid-19 di Wilayah Kampung Kroyo, Karangmalang, Sragen. Dengan adanya kegiatan pengabdian kepada masyarakat ini diharapkan warga dapat memahami dan menerapkan PHBS sebagai upaya mencegah dan menanggulangi covid-19 sehingga kasus penularan covid-19 khususnya di Wilayah Kampung Kroyo, Karangmalang, Sragen dapat berkurang.

\section{METODE PELAKSANAAN}

Kegiatan pengabdian masyarakat dilaksanakan pada Bulan April 2020 di Kampung Kroyo, Karangmalang, Sragen. Khalayak Sasaran adalah masyarakat yang berdomisili di Wilayah Kampung Kroyo, Karangmalang, Sragen. Metode kegiatan yang digunakan dalam kegiatan pengabdian masyarakat ini adalah pemberdayaan masyarakat dalam penerapan PHBS dan upaya penanggulangan covid-19 dengan kerja bakti membersihkan masjid, penyemprotan desinfektan bersama Karang Taruna Kampung Kroyo, edukasi kepada pedagang / pelaku usaha makanan di kampung kroyo untuk menyediakan sabun dan air mengalir untuk cuci tangan serta edukasi kepada pedagang tersebut untuk melakukan cuci tangan yang benar, edukasi PHBS di grup whatsapp ibu-ibu PKK. Penanggulangan covid-19 di kampung kroyo dilakukan dengan pembagikan sembako kepada warga.

\section{HASIL DAN PEMBAHASAN}

Sebelum pelaksanaan kegiatan pengabdian kepada masyarakat, dilakukan beberapa persiapan. Pertama, tim pengabdian masyarakat berkoordinasi dengan tokoh masyarakat dan tim gugus tugas di wilayah setempat untuk persiapan pelaksanaan baik waktu dan tempat pelaksanaan. Kedua, tim pengabdian masyarakat, melakukan identifikasi kebutuhan program terkait pelaksanaan pemberdayaan masyarakat dalam penerapan PHBS dan pembagian sembako. Ketiga, mempersiapkan sarana dan prasarana yang mendukung program dan materi edukasi yang diberikan serta persiapan alat kebersihan, desinfektan, dan sembako.

Pelaksanaan kegiatan pengabdian kepada masyarakat meliputi 5 kegiatan yang dilaksanakan selama 4 hari di wilayah Kampung Kroyo, Karangmalang, Sragen. Kegiatan pertama dilaksanakan pada hari Sabtu, 18 April 2020 di Masjid Baitul Mutaqin, Kroyo, Karangmalang Sragen. Kegiatan yang dilakukan adalah Kerja bakti membersihkan masjid. 


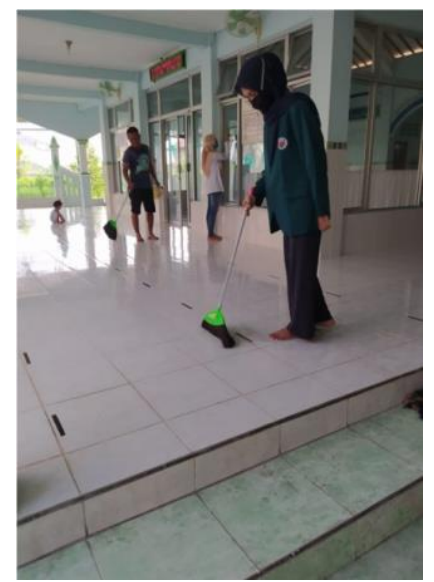

Gambar 1. Kerja Bakti Membersihkan Masjid di Masjid Baitul Mutaqin, Kroyo, Karangmalang Sragen

Masjid merupakan tempat berkumpul bagi para jamaah khususnya ketika melaksanakan ibadah, oleh karena itu area masjid perlu dibersihkan untuk mencegah penyebaran Covid-19. Pencegahan yang dilakukan antara lain menyediakan tempat cuci tangan pakai sabun dengan air mengalir atau handsanitizer, mengepel serambi, tempat pengimanan, tempat khotbah, dan lemari penyimpanan AlQur'an serta menjaga kebersihan dan lingkungan di sekitarnya. Selain membersihkan area masjid, juga dilakukan penempelan poster pada mading masjid.

Kegiatan kedua yang dilaksanakan pada hari Minggu, 19 April 2020 adalah penyemprotan desinfektan bersama Karang Taruna Kampung Kroyo.

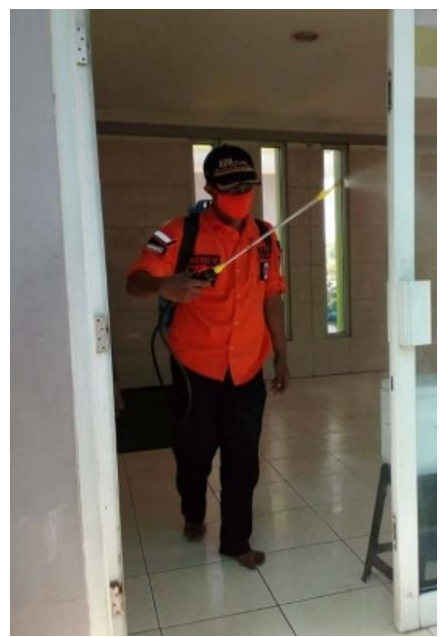

Gambar 2. Penyemprotan Desinfektan bersama Karang Taruna Kampung Kroyo

Pelaksanaan kegiatan penyemprotan disinfektan dilakukan sebagai salah satu upaya untuk mencegah menyebarnya covid-19 yang dilakukan secara langsung. Kegiatan ini juga menyadarkan masyarakat terhadap pentingnya mengantisipasi penularan Virus Corona. Pada pukul 07.00 WIB pengurus Karang Taruna dan warga setempat melakukan persiapan alat yang digunakan untuk penyemprotan. Pada pukul 08.00 WIB mulai melakukan penyemprotan oleh relawan yang menggunakan alat pelindung diri seperti sarung tangan dan masker. Penyemprotan dilakukan menggunakan alat penyemprot pertanian. Sasaran penyemprotan desinfektan seperti lantai, dinding serta benda yang paling sering bersentuhan dengan tangan pada berbagai fasilitas desa. Pada pukul 10.00 WIB penyemprotan selesai, masing-masing relawan dan warga yang turut melakukan penyemprotan membersihkan diri untuk meminimalisir kontaminasi virus.

Kegiatan ketiga yang dilaksanakan pada hari Minggu, 19 April 2019 adalah pembagian sembako kepada warga dengan tujuan membantu meringankan beban warga yang terdampak pandemi covid19. 


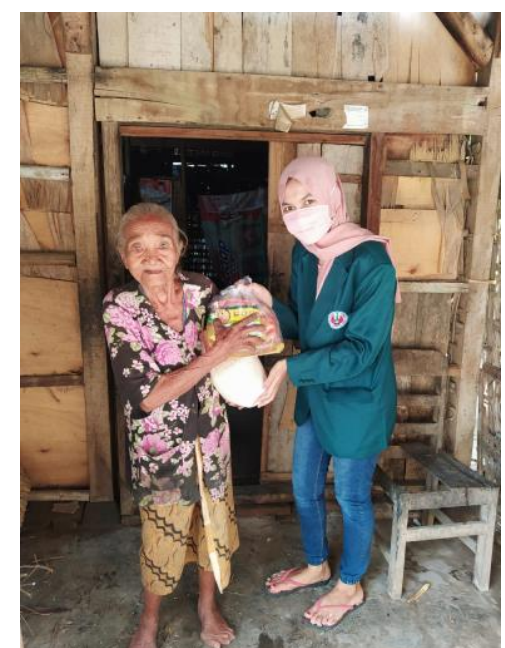

Gambar 3. Pembagikan Sembako kepada Warga

Kegiatan pembagian sembako kepada warga masyarakat yang terdampak Covid-19 diharapkan bisa membantu warga masyarakat yang sangat membutuhkan bahan pangan pokok untuk kehidupan sehari-hari terutama ditengah pandemi Covid-19, dimana ada kebijakan dari pemerintah agar seluruh masyarakat mengalihkan semua pekerjaan di rumah. Kegiatan pembagian sembako dilakukan secara langsung dan dari rumah ke rumah agar tidak berpotensi menyebarkan Covid-19. Kegiatan berlangsung dengan lancar. Respon dari masyarakat setempat, mereka sangat terbantu dengan kegiatan ini.

Kegiatan keempat yang dilaksanakan pada hari Senin, 20 April 2020 adalah edukasi kepada pedagang/pelaku usaha makanan di Kampung Kroyo untuk menyediakan sabun dan air mengalir untuk cuci tangan serta edukasi kepada pedagang tersebut dengan memberikan pengetahuan tentang pentingnya cuci tangan untuk dapat menerapkannya dengan benar.

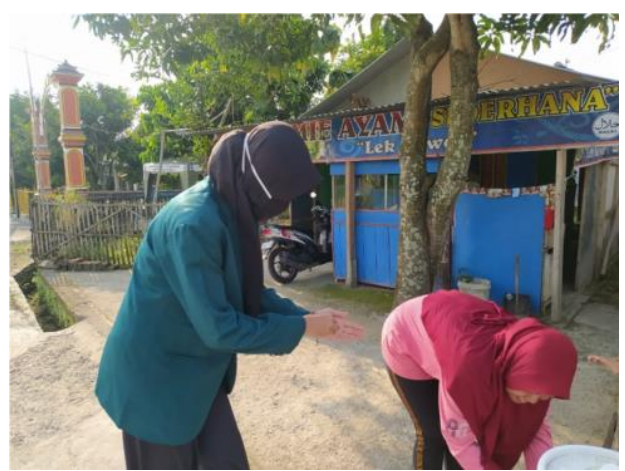

Gambar 3. Edukasi kepada Pedagang/Pelaku Usaha Makanan di Kampung Kroyo

Edukasi merupakan bagian penting untuk memberikan pemahaman tentang cara memutus rantai penyebaran Covid-19 di kalangan masyarakat secara luas, karena dengan edukasi yang diberikan kepada masyarakat, maka dengan sendirinya masyarakat saling menjaga dalam menangkal penularan Covid-19. Dengan adanya Edukasi tentang Covid-19 kepada pedagang/pelaku usaha di kampung Kroyo, Karangmalang, Sragen ini, pedagang/pelaku usaha sangat antusias mengikutinya serta menerapkan arahan untuk mencuci tangan yang dengan benar. Selain cara mencuci tangan yang baik, pedagang/pelaku usaha juga dihimbau untuk menyiapkan tempat mencuci tangan didepan warung masing-masing.

Kegiatan kelima yang dilaksanakan pada hari Rabu, 22 April 2020 adalah Edukasi PHBS di grup whatsapp ibu-ibu PKK, dengan tujuan memberikan pemahaman tentang cara memutus rantai dan memperlambat penyebaran covid-19. 


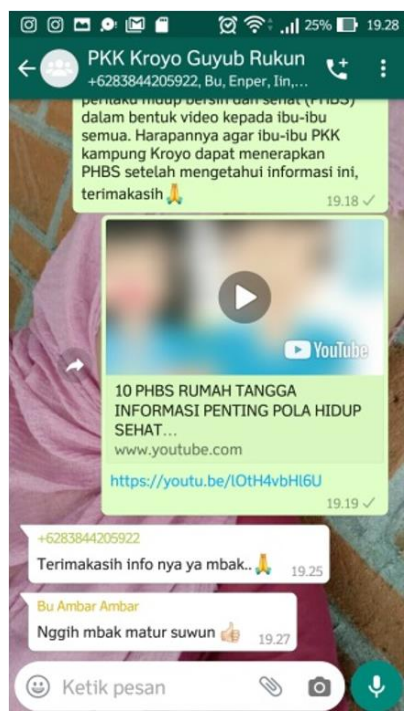

Gambar 3. Grup whatsapp Ibu-ibu PKK Kampung Kroyo

Edukasi tentang PHBS ini sangat penting. Metode edukasi yang diberikan dilakukan dengan cara, video tentang PHBS disebarkan secara online melalui grup ibu-ibu PKK kampung Kroyo melalui whatsapp. Metode edukasi melalui video ini diberikan agar ibu-ibu PKK tetap dirumah saja dan menghindari kerumunan sebagai upaya untuk pencegahan covid 19. Dalam video tersebut terdapat pesan, pentingnya PHBS terutama dalam pencegahan covid-19. Respon dari ibu-ibu PKK kampung Kroyo, mereka sangat antusias dalam menerima informasi tersebut dan sebagian besar dari ibu-ibu PKK menerapkan PHBS dalam kehidupan sehari-hari setelah mengetahui informasi tersebut.

Seluruh kegiatan pengabdian masyarakat berjalan lancar, dan tanggapan masyarakat di Kampung Kroyo, Karangmalang, Sragen terhadap kegiatan ini adalah baik sekali karena mereka merasa terbantu dengan adanya kegiatan seperti ini. PHBS merupakan salah satu starategi dalam pencegahan penyebaran Covid -19 yang sangat efektif dan mudah dilakukan oleh semua lapisan masyarakat. Dengan adanya kegiatan pengabdian kepada masyarakat ini, kami dapat membantu masyarakat dengan mengajak dan menghimbau masyarakat di Kampung Kroyo, Karangmalang, Sragen untuk senantiasa menerapkan PHBS yang dapat menjadi menjadi kunci pencegahan penyebaran Covid-19 pada masa pandemi ini.

\section{KESIMPULAN}

Pengetahuan tentang PHBS dapat dipahami dan diterapkan dengan baik oleh Warga di Wilayah Kampung Kroyo, Karangmalang, Sragen. Dengan adanya kegiatan pengabdian kepada masyarakat ini dapat meningkatkan kesadaran masyarakat tentang pencegahan dan upaya menanggulangi covid-19 di Wilayah Kampung Kroyo, Karangmalang, Sragen.

Disarankan kepada warga Kampung Kroyo, Karangmalang, Sragen untuk senantiasa menerapkan protokol kesehatan dan menerapkan PHBS dalam kegiatan sehari-hari sebagai upaya pencegahan covid-19. Untuk mencapai keberhasilan ini, perlu adanya dukungan dan keterlibatan dari seluruh warga Kampung Kroyo, Karangmalang, Sragen.

\section{Daftar Pustaka}

Beiu, C., Mihai, M., Popa, L., Cima, L., \& Popescu, M. N. (2020). Frequent Hand Washing for COVID-19 Prevention Can Cause Hand Dermatitis : Management Tips From frequent hand washing to hand dermatitis. Cureus, 12(4). https:// doi.org/10.7759/cureus.7506.

Jamilatun, M. 2019. Penyuluhan Mencuci Tangan sebagai Upaya Mencegah Kecacingan di Panti Asuhan Assomadiyyah Tangerang. Jurnal Pengabdian Pada Masyarakat, 2019, Vol. 4 No. 3, Page: 273-278. http://ppm.ejournal.id/index.php/pengabdian/article/view/154.

Jamilatun, M., Aminah A., Shufiyani. 2020. Pemeriksaan Kuku dan Penyuluhan Memotong Kuku yang Benar pada Anak-Anak di Panti Asuhan Assomadiyyah. Jurnal Abdidas Volume 1 Nomor 3 Tahun 2020 Halaman 88- 94. http://abdidas.org/index.php/abdidas. 
Karo, M. B. (2020). Perilaku Hidup Bersih dan Sehat (PHBS) Strategi Pencegahan Penyebaran Virus Covid 19. Prosiding Seminar Nasional Hardiknas, 1-4.

Kementerian Kesehatan. (2016). PHBS. http://promkes.kemkes.go.id/phbs

Rothan, H. A. dan Byrareddy, S. N. (2020). "The epidemiology and pathogenesis of coronavirus disease (COVID-19) outbreak." Journal of Autoimmunity, 102433. https://doi.org/10.1016/j.jaut.2020.102433.

Sohrabi, C. et al. (2020). "World Health Organization declares global emergency: A review of the 2019 novel coronavirus (COVID-19)," Int. J. Surg., vol. 76, no. February, pp. 71-76, 2020, doi: 10.1016/j.ijsu.2020.02.034.

Susilawati, S. R. Falefi, and A. Purwoko. (2020). "Impact of COVID-19's Pandemic on the Economy of Indonesia," Budapest Int. Res. Critics Inst. Humanit. Soc. Sci., vol. 3, no. 2, pp. 1147-1156, 2020, doi: $10.33258 /$ birci.v3i2.954.

Tabi'in, A. (2020). Perilaku Hidup Bersih dan Sehat (PHBS) pada Anak Usia Dini sebagai Upaya Pencegahan Covid 19. JEA (Jurnal Edukasi AUD), 6(1), 58-73

WHO.(2020). Tatalaksana Klinis Infeksi Saluran Pernafasan Akut Berat (SARI) Suspek Penyakit COVID-19. Jenewa: World Health Organization

WHO. WHO Director-General's remarks at the media briefing on 2019-nCov on 11 February 2020. https://www.who.int/dg/speeches/detail/who-director-general-s-remarks-at-the-media-briefing-on2019-ncov-on-11-february- 2020.

Zukmadini, A. Y., Karyadi, B., dan Kasrina, K. (2020). Edukasi Perilaku Hidup Bersih dan Sehat (PHBS) dalam Pencegahan Covid-19 kepada Anak-anak di Panti Asuhan. Jurnal Pengabdian Magister Pendidikan IPA, 3(1), 68-76. 